\title{
Capital Punishment and Drug Trafficking: An Ethical Appraisal
}

\author{
FALANA KEHINDE \\ General Studies Unit, Federal University of Technology, Akure
}

\begin{abstract}
The people and the Government of every country are now fighting another world war which is an all embracing and a tedious one. It is the war against drug addiction and trafficking. They are using every weapon at their disposal to fight it and to also curb the rate of its followers which are the addicts and as well as to stem the tide of its propagandists which are the traffickers. Among the penal codes of every country is the law against drug trafficking. This article focuses on capital punishment and drug trafficking and their ethical appraisal. It tries to see whether capital punishment is a morally justifiable system of criminal law and justice for the offence of drug trafficking. It founds out that there are problems with the use of capital punishment for the offence of drug trafficking. The article also shows that making drug trafficking a capital offence is immoral and it is not a requirement of justice, because capital punishment appears too severe for drug trafficking.
\end{abstract}

Keywords: Drug, Addiction, Law, Capital Punishment

DOI: $10.7176 / \mathrm{JCSD} / 54-04$

Publication date: December $31^{\text {st }} 2019$

\section{DRUG DEFINED}

A drug is any substance which when taken into a living organism may modify one or more of its functions. Substances such as cocaine, heroin, nicotine( in cigarettes), caffeine ( in coffee and kolanuts), alcohol ( in beer and wine) are all classified as drugs ${ }^{1}$.

Drug is also an original, simple, medicinal substance, organic or inorganic, used by itself or as an ingredients in medicine, or a commodity which is no longer in demand and so unsaleable ${ }^{2}$. It is any chemical agent that affects the function of living things. It is used in treating, curing ,diagnosing, mitigation and prevention of diseases ${ }^{3}$. It is therefore able to affect the functioning of living things, by interrupting the extensive chemical system of communication, that regulates the integrated functioning of the cells of organism ${ }^{4}$.

Commonly used drugs are antibiotics, stimulants like tranquilizers, hypriotics, cocaine and sedation. Others are narcotics like opium and heroin, oral contraceptive, alcohol, depressants, cardiovascular drugs, immunosuppressive drugs, whole blood, nicotine, plasma, caffeine and wide variety of preparation for specific purpose.

\section{DRUG ABUSE AND ADDICTION}

A drug is said to be abused when its use is not medically necessary. It is excessively used even when it is socially acceptable. This is another way of saying that drugs can be abused when it is used against legal prohibition. These are how drugs are being abused. This means that virtually any drug can be abused.

Drug dependent persons are usually referred to as drug abusers. Drug abuse is an excessive maladaptive use of drugs for non medical purposes, despite social, psychological and physical problems that may arise from such use $^{5}$.

The important questions that arises are what is the criterion for an abuse of drugs? Is it when I am taking unprescribed drug stupidly that I can be said to abuse drugs? What if my excess use of drugs does not lead to any psychological, social and physical problems, will my excess use of drugs still be an abuse of drugs? If I consider the taking of excess drugs as what will make me solve a difficult chemistry or mathematical problem, is that a drug abuse or an abuse of what will help me get out of my chemistry or mathematical mess?

This definition of drug abuse is ambigious because it is not clear whether if I take the drug to suit my own purpose, it is still an abuse or only when it affects me negatively. The definition of drug here is still the excessive use of drugs, because excessive use of drugs are of benefits to some people. Some people cannot talk freely and confidently if they have not taken excessive alcohol. There are even some people who strongly believe that for them to be able to read for an examination, they take kolanut to avoid sleeping while reading. Also, some people cannot perform well in an examination when they have not engaged themselves in smoking cigarettes before such an examination.

Addiction to drug is also described as the periodic or chronic intoxication which is detrimental to the user and the society ${ }^{6}$. These definitions of addiction are based on improper criteria. I may be an addict without necessarily being a disturber of the societal peace because the ends being sought through the use varied. Relief from pain, fatigue or anxiety, celebration if social solidarity, kicks and enhanced mystical experiences . If I use drugs to get relief from pain or if my addiction to a particular drug relieves me of anxiety or stress, is such an addiction detrimental to the society or to me? No, it is not detrimental to me because in the short run, it rather 
promotes my happiness by getting me out of a stress and whatever promotes happiness should not be seen as an immoral thing.

\section{HOW TO KNOW A DRUG ADDICT}

There are various ways of identifying a drug addicted person. Such includes, possession of drugs, peculiar plants, or butts, seeds or leaves in ashtrays or clothing pockets. There is also odour of drugs, smell of incense or other cover up ${ }^{7}$. This is because a drug addicted person, each time that he takes drugs, will always like to cover up the smell by using either body sprays or perfumes for people not to suspect him. He may even go as far as taking sweets such as butter mint and tomtom.

There is also identification with drug culture which are drug related magazines, slogans on clothing, hostility in discussing drugs because anyone who is a drug addict would be frowned at by people anytime they are discussing something peculiar to drugs.

A drug addicted person at times may be too active. This is because, there are some addicted people whereby when they have not taken their drugs, might appear gentle and simple, but the moment they are on drugs, they are hyper active. They are always eager to answer questions in the class anytime the lecturers are teaching them. These set of people are very courageous when they are on drugs. Though there are some drug addicted people that their own symptom is sluggishness. They tend to be sluggish when they are on drugs.

Signs of physical deterioration which include memory lapses, short attention span, difficulty in concentration. This is because a drug addict, due to his addiction to drugs, easily forgets things because there is difficulty in concentrating on what he intends to do. There is also poor physical coordination, slurred or incoherent speech, unhealthy appearance, indifference to hygiene and grooming.

Moreover, there are also changes in behavior, which include distinct downward performance in school or working place, increased absenteeism or tardiness, chronic dishonesty, lying, cheating, stealing, trouble with police, changes of friends, evasiveness in talking about new ones, increasing and inappropriate anger, hostility, irritability, secretiveness, reduced motivation, energy, self discipline, self esteem. These are some of the various signs by which we can identify a drug addict.

\section{DRUG TRAFFICKING AND THE LAW.}

Drug trafficking is the drug distributive trade, from the time the drug is being processed to the time it is sold in small quantities on the street ${ }^{8}$. Many people frown at drug trafficking because they believe that the trade promotes the number of criminals on the street and because of the consequential behavioral life of addicts. They advocate war against drug trafficking also because, it is believed that drug addiction can spoil or destroy some vital functioning organs of the body and as stimulants some nerves in the brain and render than(that is addicts) unhealthy both in conduct and in appearance. But these are not enough reasons why those who promote the sales of drug be arrested and prohibited. Criminality does not necessarily follow addiction, though in United States of America, an addict is defined as a criminal and stereo typed as a dope.

British courts are now punishing drug traffickers not just with jail sentences, but by seizing their illegal gains. This is a clear result of the drug trafficking offences act which came into force in January 1987. Courts have already used it to order the seizure of assets totaling more than 16 million pounds and to freeze a further twenty million pounds( fair brain 1990) ${ }^{9}$. Also China has launched a nation wide anti drug campaign aimed at eliminating trafficking and use within two or three years, the China daily said on $25^{\text {th }}$ June, 1991 .

Hard drug offence in Saudi Arabia even carries death sentences. But the only problem is that it is not clear may be it is when the drugs are found in someone s luggage, or when the drugs are found on the person that he can be called a peddler. Former American president, George Bush voted about 1.9Billion in military and economic aid in the 1990 budget year starting on October 1, 1989 to battle cocaine production and marketing in Colombia, Peru and Bolivia over the next five years.

Authorities in Ghana have passed a stiff drug law to crack down on illicit narcotic dealers, according to an official announcement in Accra on $26^{\text {th }}$ May, 1990. It said an operation was also launched on Friday $25^{\text {th }}$ May, 1990. Night hand begun rounding up Ghananian "drug barons"10.

Section 10 A of Decree No 48 of $29^{\text {th }}$ December , 1989 of Nigeria says that any person who without lawful authority imports, manufacturers, produces , process, plants or growth the drugs popular known as cocaine, LSD, heroine or any other similar drugs shall be guilty of an offence and liable on conviction to be sentenced to imprisonment for life ${ }^{11}$. Although, it should be noted that there are some of these drugs which are both preventive and curative in nature. Cocaine, for instance is recommended to some patients as curative medicine, but this is not to say that the Government should legalize drug peddling. For instance if I take caffeine( in kolanuts) and it relieves me from stress, this type of drug is curative to me, but the only problem is that I might be acting against my long term interest . 


\section{THE ETHICS OF CAPITAL PUNISHMENT}

The term capital punishment derives from "Caputa" a word used by the Romans, variously to mean "the head, "the life", or the civil rights" of an individual ${ }^{12}$. Capital punishment means, the officially authorized execution of the death penalty of persons determined by appropriate legal procedures to have committed a criminal offence. Capital punishment is at present, a prominent feature of the administration of criminal justice in many nations of the world. It was administered for crimes of murder, coup detat, treachery, rape, armed robbery and recently drug trafficking.

Capital punishment as it emerges in civilized society presupposes a system of criminal law, predicated the assumption that certain harms committed by one individual upon another, represents injuries to the interest of the corporate society and hence are punishable by the society. In this respect, the society has no right to terminate life just because it assumes that the individual has committed an offence that is of injury to the interest of the society.

If capital punishment is legislated because its predication on the assumption that the act of an individual is of injury to others, then it is not a just criminal law. Capital punishment is basically an immoral criminal law based only on assumptions. It is applicable in some countries, and it is not applicable in other countries for some particular offences. If it is a just system of criminal law, it should have been universalized. This means that capital punishment is based on some emotions of individuals, it is as a result of cultural emotivism and a system of criminal law that is based on emotions. It is not based on justice and if it is not based on justice, then it should be erased from the curpus of criminal law and justice.

Moreover, in Nigeria today, we often hear of sharia law whereby capital punishment been meted out on people. There had been cases where hands are been cut off . individuals have been executed in many ways by gas, by electrocution, by fireams and so on. These means of killing are basically immoral ways because it is not based on Justice. Any country still using capital punishment for the offence of drug trafficking to me, is yet to be civilized. This is because any country these days who claims to be truly civilized should have actually made away with capital punishment as a way of dealing with drug traffickers.

Capital punishment, now abolished in England, was historically a significant form of punishment in that country. It has been estimated that Henry VIII executed 72,000 thieves and vagabonds. England has only eight major crimes like treason, petty treason, killing of husband by wife, murder cancery, robbery, burglary, rape and $\operatorname{arson}^{13}$, but it is now a thing of the past due to civilization. Anybody who is sentenced to death by any of the methods of capital punishment can appeal to court.

The question now is can we have an alternative to capital punishment in dealing with drug trafficking?

\section{CONCLUSION}

Life imprisonment should have been better for punishing drug traffickers than capital punishment, but the problem is that life imprisonment is more deterring to drug traffickers than capital punishment because to be incarcerated for a life time in a rotten jail is more deplorable as there will be no question of dying once, but it will be slow and gradual painful death. Again, there had been cases of prisoners breaking jail with the intention of killing those who put them there . some prisoners had even been released during revolution.

The humanitarians have prescribed the therapeutic treatment for drug pushers because it stimulate or arouses individuals the wish and hope of intention to change his method of dealing with realities of life which is lacking in his present penal system and the existing philosophy. But there had also been cases of those who still go back to the business after the therapeutic treatment.

Mutilation is another form of approach to drug problem which should have been considered and which some people believe will scare people away from drug trafficking because some fear to loose any part of their bodies. They prefer death than to loose their body or be maimed for life. Mutilation to me, is nothing but capital punishment in the critical aspect of it. There had even been cases whereby innocent peoples hands had been cut off before they now realized that such people are innocent.

I am of the opinion that rehabilitation should be adopted in putting a stop to drug trafficking. This is because the goal of modern correctional thought must not be revenge, not penance, not punishment but rehabilitation. A drug addicted person, when rehabilitated can still be useful to the community where he belongs. We have a lot of rehabilitation homes in the country where such people can still be corrected of their wrong deeds. In such places, we have a lot of people like the psychologists who educate such people on the danger of taking hard drugs. The theory of rehabilitation is based on the belief that healthy rational people will still be useful to the community.

Rehabilitation is also said to be the way the way that criminal justice system can significantly reduce crime. These days we see people giving testimonies in churches on how they are been rehabilitated . such people are able to give such testimonies because they are alive. If they had been killed one way or another, they would not have been able to look back and realize their misdeeds, hence they would not have shown remorse.

Another more tenable way of handling the drug problem is that when a drug baron is caught with enough 
evidence, he or she should be tried publicly and enough publicity should be given to his trial. This is because there are some rich and influential people that are behind the drug barons. Such people should be exposed because nobody should be above the law, this to me will make the law to be consistent because nobody will want to soil his name if he is connected with drug business.

The most important thing is that our children should have proper education from the elementary level on the danger of dealing in hard drugs. This is because it is what they are taught when are young that they will adhere to when they grow up. If all these are strictly adhered to, I believe the issue of drug trafficking will be a thing of the past in our society

\section{REFERENCES}

1. Basic Guide to Drug Abuse Counselling: National Drug law enforcement Agency Radient press limited P.1

2. The shorter oxford English Dictionary an Historical principles( Clareon press, Oxford England 1973, P.611

3. The new Encyclopedia Bitanica (Enclopedia Bitannica 1992) vol. 4,P.252

4. E.F. Bozman: Everymans Encyclopedia( London: J.M. Deut and sons (Ltd). Vol.3,P111

5. David L. Sills: Internal Encyclopedia of social sciences vol. 1 and 2 (Crowell Collier and Macmillan (inc) 1968 P.292

6. David Hume : Enquiry concerning Human understanding ( Oxford University press Ely House London P.60

7. The A,B,C, of Drug Abuse: National Drug law Enforcement Agency(A publication of N.D.L.E.A.) P.2

8. John Irabor, "pushers cut a hard kick", magazine , February 4, 1985 P.15

9. Emmanuel Adeyeye : Hard Drugs, Global threat to mankind. ISBN 978-306-75-8-3( Published by Adedayo pressP.45

10. Sue Titus Reid: Crime and Criminology second edition Pryden press 1976P.530

11. Decree NO 48,National Drug Law Enforcement Agency( $29^{\text {th }}$ December, 1989

12. Elizabeth Telfer : New Catholic Encyclopedia ( The Catholic University press W.D.C. 1968,P.78

13. George Haskins : A Rule to walk( Boston little down 1969 P.3 